\title{
THE ACTION OF RUSSIA IN REGARD TO ALCOHOL.
}

\author{
BY JAMES Y. SIMPSON, M.A., D.SC., F.R.S.E., \\ Professor of Natural Science, New College, Edinburgh; Author of \\ "Sidelights on Siberia," etc.
}

THE whole world has been amazed by the remarkable action taken by Russia to arrest alcoholism. No social event connected with the war has proved of such world-wide interest.

An experiment so directly affecting public health could not fail to attract the attention of physicians and surgeons throughout the area covered by it. In particular, Dr. Alexander L. Mendelson, of Petrograd, a distinguished neurologist, and member of the Petrograd Town Council, has investigated the whole matter in very many of its aspects. His results were communicated in a report made to the Russian Society for the Preservation of National Health in March 1915. I had an opportunity of discussing his conclusions with him, and am able to present the most striking of them, along with data collected by him subsequent to the delivery of the paper.

The results of the prohibition of vodka in Petrograd were immediately seen in a very sharp decline in the number of arrests for drunkenness. These are best indicated by contrasting periods of a half-year, thus :

Number of Arrests of Men for Drunkenness in Petrograd. 1913.

$\begin{array}{cc}\text { First Half: } & \text { Second Half- } \\ \text { Year. } & \text { Year. } \\ \mathbf{3 0 , 5 1 0} & \mathbf{3 3 , 8 3 0}\end{array}$

\begin{tabular}{|cc|}
\multicolumn{2}{|c|}{1914.} \\
First Half- & Second Half- \\
Year. & Year. \\
29,461 & 12,242
\end{tabular}

If we take a single district in the city during 1914, and watch the arrests by the month, the following descending scale is obtained :

$\begin{array}{rrrrrrrr}\text { May. } & \text { June. } & \text { July. } & \text { Aug. } & \text { Sept. } & \text { Oct. } & \text { Nov. } & \text { Dec. } \\ 917 & 666 & 474 & 123 & 100 & 71 & 56 & 31\end{array}$




\section{I56 The British Journal of Inebriety}

These numbers indicate arrests simply for drunkenness. In Russia punishment would not follow for drunkenness alone unless the prisoner had proved disorderly. In view of these remarkable decreases, it was no surprise to learn that hardly any pledges were now being taken at the Temperance Church near the Warsaw Station.

The next series of statistics relates to the Obukhov City Hospital, which has special wards for the care of cases of serious alcoholic poisoning, such as are handed over by the police for treatment. The number of deaths was as follows :

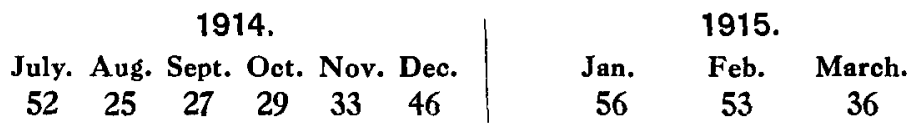

It will be noticed that there was a sharp decrease in the initial months of the war, but that the higher rates again asserted themselves; they mean, in fact, a higher death-rate for a smaller number of drinkers. The anomaly is, of course, explained by the character of the substitutes used. Kvass, with its half per cent. of alcohol, was mixed with methylated spirits, or the latter were swallowed " neat." Now, while vodka has 40 per cent. of alcohol (and in 1910 some three million vedros* of vodka were consumed in Petrograd alone), this "denatured" spirit has an alcohol percentage of 93. Accordingly, any marked increase in its consumption is bound to have very serious effects. The extent of the evil may be gauged by the following figures, showing the increase in the number of vedros sold during the first three months of the years in question, the principal use being, however, for burning purposes :

$\begin{array}{ccc}1913 . & 1914 . & 1915 . \\ 103,447 & 112,524 & 170,221\end{array}$

The sale of " denatured" spirit is now under very strict control. "Politura," which, when mixed with shellac, gives a varnish, can only be sold now under licence.

A third series of statistics shows the effect of prohibition on cases of mental derangement directly due to alcoholic causes. In the Obukhov Hospital the number of cases for the first three months of the years 1913,1914, 1915, was 114, 117, and 67 respectively. The death-rates were 7,6 , and 9 per cent. respectively, 
the last highest rate being due to the harder drinking of poison. ous substitutes. The statistics for all mental cases for the whole city (30 per cent. of them being due to alcohol) was 998 for the last six months of 1913 , and 794 for the corresponding period in 1914. Of traumatic cases taken to hospital, most of them drunken, the figures for the five months July to November, 1913, were 710 ; the following year, for the corresponding period, they had fallen to 237. Methyl alcohol, as is well known, especially affects the optic nerves very profoundly, and may be a direct cause of actual blindness. In the Eye Hospital in Petrograd there were treated 72 cases with impaired vision due to this specific cause from July, 1914, to April, 1915, eight of whom had become blind. Previously such cases were absolutely insignificant in number.

Another series of statistics bore on the suicide-rate in Petrograd, limited in the first instance to poison cases (as by acetic acid, etc.) brought to the Obukhov Hospital. Of such, during the five months July to December, 1913, there were 97 cases ; for the corresponding period in 1914 there were only 16 cases. A larger series relates to the total number of deaths by suicide in every form in Petrograd. They are as follows for the year 1914 :

\begin{tabular}{cc|cc}
\multicolumn{2}{c|}{ MEN. } & \multicolumn{2}{c}{ WOMEN. } \\
First Half- & Second Half- & First Half- & Second Half- \\
Year. & Year. & Year. & Year. \\
202 & 79 & 123 & 95
\end{tabular}

For the city of Warsaw the total number of suicides and attempts at suicide of both sexes during the first half of 1914 was 442 ; for the second half of the year the total was 229 .

Dr. Mendelson has further included statistics dealing with other aspects of the question than those that are purely medical. The reduction in the number of small loans (one to five rubles)mostly on clothing-made by the pawnshops in Petrograd is shown by these figures for the second half-year in either case : $1913,177,585$; and 1914, 113,306.

The increases in the deposits in the Savings Banks were as follows for all Russia, in millions of rubles : For July, 1914, the figure was 41.1 less than in the previous year, but for the succeeding months to the end of the year the figures show these progressive increases : August, 10॰1 ; September, $25^{\circ} 8$; October, $21{ }^{\circ} 7$; 
November, 24.8 ; December, $29^{\circ} 1$. In the case of the Imperial Savings Banks, the figures of difference in millions of rubles are as follows for the first three months in each case :

$\begin{array}{ccc}1913 . & 1914 . & 1915 . \\ +6 \cdot 7 & -1 \cdot 2 & +149^{\circ} 6\end{array}$

For Petrograd alone the corresponding figures are :

$\begin{array}{lll}1913 . & 1914 . & 1915 . \\ +2 \cdot 1 & +0 \cdot 8 & +12 \cdot 3\end{array}$

and for Moscow :

$\begin{array}{ccc}1913 . & 1914 . & 1915 . \\ +1.8 & +1.7 & +80^{\circ}\end{array}$

All these figures are official. For the first five months of 1915 the total savings represent a gain of 200 million rubles. These are savings from drink and the allowances payable to the wives of soldiers, and they do not represent the absolute savings, because these are partly expressed in better clothing and better feeding. But when we consider that some 840 million rubles were spent on vodka in 1914, and that the Government was counting on the figure rising to 900 millions in 1915, we can realize what an economic transformation must have taken place in the country.

The actual cost of making a vedro of vodka was 80 kopecks, but additional rectification, transport, and selling charges, made the selling price of the distiller to the Government two rubles a vedro. This the Government retailed at eight rubles according to the strength of the beer. On beer not over 3.6 alcoholic strength the tax is six rubles, and if the production of the brewery is not more than 2,000 vedros annually, the tax is only three rubles. On higher strength the tax is nine rubles. 